\title{
Cytomegalovirus DNA detection on Guthrie cards in patients with neonatal cholestasis
}

\author{
Björn Fischler, Pia Rodensjö, Antal Nemeth, Marianne Forsgren, Ilona Lewensohn-Fuchs
}

\begin{abstract}
Aim-To time the onset of cytomegalovirus (CMV) infection in patients $(n=39)$ with $\mathrm{CMV}$ associated neonatal cholestasis by analysing CMV DNA on Guthrie cards sampled at 3 days of age.

Methods-CMV infection was diagnosed by serology/urine isolation or by CMV DNA detection (polymerase chain reaction) in liver biopsy specimens. In order to time the infection dry blood filter paper discs were punched out from stored Guthrie cards. After phenol-chloroform extraction CMV DNA was detected by nested polymerase chain reaction.

Results-All cards from control children $(n=8)$ with congenital CMV tested positive; none of the negative controls $(n=4)$ did so. Two of 39 cholestatic infants were CMV DNA positive; their mothers had serological signs compatible with infection during the second half of the pregnancy. All other cholestatic infants tested negative.

Conclusions-CMV DNA was not detected in most of the children using Guthrie cards, suggesting that infection developed at or soon after birth.
\end{abstract}

(Arch Dis Child Fetal Neonatal Ed 1999;80:F130-F134)

Keywords: Guthrie cards; neonatal cholestasis; cytomegalovirus

Neonatal cholestasis can be defined as a clinical and biochemical manifestation of a decreased intracanalicular bile flow in infants below 6 months of age. Despite a long list of possible aetiologies for neonatal cholestasis, more than half of the cases remain unexplained. ${ }^{1}$ Viral infections have been accepted as one of the causes for intrahepatic neonatal cholestasis, ${ }^{1}$ and more recent studies have also suggested a link between certain viral infections and extrahepatic biliary atresia (EHBA). ${ }^{2}$

In a previous study we found that cytomegalovirus (CMV) infection was associated with both intrahepatic neonatal cholestasis and EHBA. ${ }^{4}$ As the infants were investigated at a mean age of 8 weeks it was not known whether they were infected before, during, or after birth. A diagnosis of congenital CMV infection requires that CMV IgM in the serum or CMV excretion be detected before 3 weeks of age. ${ }^{5}$

In this study we developed a method to analyse CMV DNA using polymerase chain reaction (PCR) on stored, dried, blood spot filter papers (Guthrie cards), which are routinely collected at the age of 3 days. This method was used to investigate the time of viral transmission in a group of patients with CMV associated neonatal cholestasis.

\section{Methods}

Two groups (groups A and B) of infants who had clinical and biochemical signs of cholestasis were included. In group A (table 1) all patients had signs of ongoing CMV infectioneither CMV IgM detected in serum and/or CMV isolated in the urine. In group B (table 2) the patients were both CMV IgM and urine isolation negative. They were, however, CMV IgG positive and had CMV DNA detected by PCR, or CMV isolated in their liver biopsy specimens.

Group A comprised 32 infants (18 girls and 14 boys, median age 60 days, range 30-220 days), 11 of whom had EHBA. Twenty of the 32 infants had been included in a previous study. ${ }^{4}$ Maternal sera from the time of the infants' investigation were available in 26 of 32 cases. In two of these 26 mothers CMV IgM was detected in serum collected 1 and 2 months after delivery, respectively. For 14 of the 26 mothers both pre- and post delivery sera were available. Six of these 14 mothers had an increase in IgG titres between the two samples; one had an IgG seroconversion, while seven had static IgG titres.

Group B included seven cholestatic infants (five girls and two boys, median age 55 days, range 35-105 days) from the previous study. ${ }^{4}$ Five of these infants had EHBA. Maternal sera were available in six of seven cases, all of which were CMV IgG positive. Paired sera were available for only one of the mothers, where the CMV IgG titres were static.

All infants in groups $\mathrm{A}$ and $\mathrm{B}$ were investigated for genetic, metabolic, and infectious causes of neonatal cholestasis. ${ }^{1}$ Needle biopsy of the liver was performed according to the method of Menghini. ${ }^{6}$ Hepatobiliary scintigraphy was performed if EHBA was suspected. This diagnosis was finally confirmed by laparotomy and perioperative cholangiography.

Eight patients with confirmed congenital CMV infection-detection of CMV IgM in serum and/or CMV isolated in urine before 3 weeks of age ${ }^{5}$ served as positive controls.

Stored Guthrie cards from each infant, collected at 3 days of age for the purposes of diagnosing certain inborn errors of metabolism, were analysed for CMV DNA, using PCR.

A $50 \mu \mathrm{l} \mathrm{CMV} \mathrm{harvest} \mathrm{from} \mathrm{fibroblasts} \mathrm{(tissue}$ culture, titre $6.4 \times 10^{-4}$ ) in tenfold dilutions, $\left(10^{0}\right.$ to $10^{-6}$ and $5 \times 10^{-3}$ to $\left.5 \times 10^{-5}\right)$ was added to dried capillary blood on Guthrie cards from 
Table 1 CMV status of 32 mothers (serology, prenatal/postnatal if available) and their cholestatic infants (CMV-IgM, urine isolation, CMV-DNA in liver biopsy specimens and CMV-DNA on Guthrie cards) in group $A$

\begin{tabular}{|c|c|c|c|c|c|c|c|c|}
\hline $\begin{array}{l}\text { Patient } \\
(\operatorname{sex})\end{array}$ & Diagnosis * & $\begin{array}{l}\text { Aget } \\
\text { (days) }\end{array}$ & $\begin{array}{l}\text { 1st trimester } \\
C M V \text { serology }\end{array}$ & $\begin{array}{l}\text { Maternal CMV } \\
\text { serologyt }\end{array}$ & $\begin{array}{l}\text { IgM } \\
\text { infant }\end{array}$ & $\begin{array}{l}\text { Urine } \\
\text { infant }\end{array}$ & $\begin{array}{l}C M V-D N A \\
\text { liver }\end{array}$ & $\begin{array}{l}\text { CMV-DNA } \\
\text { Guthrie card }\end{array}$ \\
\hline $1(\mathrm{f})$ & EHBA & 220 & & & + & + & & - \\
\hline $2(\mathrm{f})$ & EHBA & 80 & IgG+ & IgG+ & + & - & - & - \\
\hline $3(\mathrm{~m})$ & EHBA & 30 & & & + & + & + & - \\
\hline $4(\mathrm{~m})$ & EHBA & 60 & & IgG+ & + & + & - & - \\
\hline $5(\mathrm{f})$ & EHBA & 180 & & IgG+ & + & - & & - \\
\hline $6(\mathrm{f})$ & EHBA & 60 & & $\operatorname{IgG}+/ \operatorname{Ig} M+$ & + & + & - & + \\
\hline $7(\mathrm{~m})$ & EHBA & 100 & & $\mathrm{IgG}+$ & + & + & + & - \\
\hline $8(\mathrm{~m})$ & EHBA & 55 & IgG+ & IgG+ & - & + & & - \\
\hline $9(\mathrm{~m})$ & EHBA & 65 & IgG+ & IgG++ & + & + & + & - \\
\hline $10(\mathrm{~m})$ & EHBA & 120 & & & - & $+\neq$ & & - \\
\hline $11(\mathrm{f})$ & EHBA & 65 & & & + & + & + & - \\
\hline 12 (f) & AATD & 40 & & IgG+ & + & - & & - \\
\hline $13(\mathrm{~m})$ & AATD & 60 & IgG+ & IgG+ & + & - & & - \\
\hline $14(\mathrm{~m})$ & AATD & 75 & & IgG+ & + & + & & - \\
\hline $15(\mathrm{f})$ & AATD & 60 & & IgG+ & + & + & & - \\
\hline $16(\mathrm{f})$ & PFIC & 50 & & IgG+ & + & - & & - \\
\hline 17 (f) & PFIC & 40 & & IgG+ & + & + & & - \\
\hline $18(\mathrm{f})$ & Alagille & 180 & & & - & + & & - \\
\hline $19(\mathrm{f})$ & Alagille & 30 & $\mathrm{IgG}+$ & $\mathrm{IgG}+$ & + & - & - & - \\
\hline $20(\mathrm{~m})$ & Aagenaes & 30 & & IgG+/IgM+ & + & + & & + \\
\hline $21(\mathrm{f})$ & NS & 50 & & IgG+ & + & + & & - \\
\hline 22 (f) & NS & 45 & IgG+ & IgG++ & + & + & & - \\
\hline $23(\mathrm{~m})$ & NS & 40 & IgG- & IgG+ & + & + & - & - \\
\hline $24(\mathrm{f})$ & NS & 60 & IgG+ & IgG+ & - & + & & - \\
\hline $25(\mathrm{~m})$ & NS & 55 & IgG+ & IgG+ & + & + & + & - \\
\hline $26(\mathrm{~m})$ & NS & 90 & IgG+ & & + & + & & - \\
\hline 27 (f) & NS & 85 & IgG+ & IgG++ & + & & & - \\
\hline $28(\mathrm{~m})$ & NS & 40 & IgG+ & IgG++ & + & + & & - \\
\hline 29 (f) & NS & 40 & & IgG+ & - & + & & - \\
\hline $30(\mathrm{~m})$ & NS & 90 & IgG+ & IgG++ & + & + & & - \\
\hline 31 (f) & NS & 50 & $\mathrm{IgG}+$ & IgG++ & + & & & - \\
\hline $32(\mathrm{f})$ & NS & 90 & IgG+ & IgG+ & - & + & & - \\
\hline
\end{tabular}

^ EHBA = Extrahepatic biliary atresia; AATD $=\alpha$-1-antitrypsin deficiency; PFIC $=$ Progressive familial intrahepatic cholestasis; Alagille syndrome, syndromic paucity of intrahepatic bile ducts; Aagenae's syndrome, chronic intrahepatic cholestasis with lymphoedema; NS = Non-specified neonatal cholestasis.

† At the time of the infant's investigation.

¥ Virus isolation not performed, however, CMV-DNA was positive by PCR.

CMV IgG negative adults. CMV genome of known concentrations was also added to discs, $5 \mathrm{~mm}$ in diameter, containing CMV negative blood. CMV DNA/100 fg DNA/ $\mu$ l (AD169, extracted from virions, Department of Virology, Swedish Institute for Infectious Disease Control) corresponding to 425 molecules was diluted to $10 \mathrm{fg} / \mu \mathrm{l}, 5 \mathrm{fg} / \mu \mathrm{l}, 1 \mathrm{fg} / \mu \mathrm{l}$ and $0.1 \mathrm{fg} / \mu \mathrm{l}$. Non-infected dried blood spots from CMV IgG negative adults were used as negative controls and dried blood spots from two CMV IgG positive adults were also used for comparison.

GUTHRIE CARDS

After examination for inborn errors of metabolism, the Guthrie cards were packed in bundles and stored at $4^{\circ} \mathrm{C}$. In groups $\mathrm{A}$ and $\mathrm{B}$ the oldest card in this study had been sampled in 1988. In the positive control group the oldest card had been stored since 1979. The samples from the Guthrie cards were punched out with a stainless steal puncher, yielding discs of $3 \mathrm{~mm}$ in diameter. To prevent contamination, the puncher was cleaned after each separate Guthrie card, by punching new clean filter papers approximately 30 times between each card. ${ }^{7}$ Two discs from each card were used for the extraction of CMV DNA. This was compared with the use of three discs from each card.

If a CMV DNA positive patient sample was detected, the Guthrie cards packed immediately before and after the positive sample in the stored bundles were analysed for CMV DNA. This was made to assess the possibility of carryover of CMV DNA between cards from different babies.
DNA EXTRACTION AND PCR METHODS

Two different extraction methods were evaluated. The first method was performed according to a protocol from Johansson et al. ${ }^{8}$ The second method was used to simplify the extraction step with phenol-chloroform. A comparison between different primer pairs in the PCR reactions was also performed.

\section{Extraction method I}

The filter paper was digested with $250 \mu \mathrm{l}$ buffer (200 mM TRIS-HCl, pH 7.4, 1.5\% SDS, 200 $\mathrm{mM}$ 2-mercaptoethanol, $20 \mathrm{mM}$ EDTA and $54 \%$ sucrose), $250 \mu \mathrm{l}$ distilled water and $30 \mu \mathrm{l}$ proteinase $\mathrm{K}(2.5 \mathrm{mg} / \mathrm{ml})$ and incubated at $56^{\circ} \mathrm{C}$ for between two and four hours. The sample was then extracted with $500 \mu$ phenol, followed by a 10 minute centrifugation (14000 $\times g$ ). The water phase (upper phase) was collected and $500 \mu \mathrm{l}$ phenol-chloroform (1:1) was added before the sample was centrifuged $(14000 \times g)$ for 5 minutes. The water phase was collected and the phenol-chloroform extraction was repeated twice. At the last extraction $500 \mu \mathrm{l}$ chloroform was added to the water phase followed by a 5 minute centrifugation $(14000 \times g)$. The water phase was collected and $500 \mu \mathrm{l} 99 \%$ ethanol and $3 \mathrm{M}$ sodium acetate $(5: 1)$ was added and the sample was incubated at $-70^{\circ} \mathrm{C}$ for 30 minutes. After incubation the sample was centrifuged (14000 $\times g$ ) for 20 minutes. The supernatant fluid was discarded and the pellet was washed with 500 $\mu 170 \%$ ethanol and centrifuged $(14000 \times g)$ for 10 minutes, then the supernatant fluid was discarded and the pellet was dried overnight. The 
Table 2 CMV status of seven mothers (serology, prenatal/postnatal if available) and their cholestatic infants (CMV-IgM, urine isolation, CMV-DNA in liver biopsy specimens and CMV-DNA on Guthrie cards) in group B

\begin{tabular}{|c|c|c|c|c|c|c|c|c|}
\hline $\begin{array}{l}\text { Patient } \\
(\operatorname{sex})\end{array}$ & Diagnosis & $\begin{array}{l}\text { Age* } \\
\text { (days) }\end{array}$ & $\begin{array}{l}\text { 1st trimester } \\
\text { CMV } \\
\text { serology }\end{array}$ & $\begin{array}{l}\text { Maternal } \\
\text { CMV } \\
\text { serology* }\end{array}$ & $\begin{array}{l}\text { IgM } \\
\text { infantf }\end{array}$ & $\begin{array}{l}\text { Urine } \\
\text { infant }\end{array}$ & $\begin{array}{l}C M V-D N A \\
\text { liver }\end{array}$ & $\begin{array}{l}\text { CMV-DNA } \\
\text { Guthrie }\end{array}$ \\
\hline$A(f)$ & EHBA & 35 & \multirow{7}{*}{ IgG+ } & IgG+ & - & - & + & - \\
\hline $\mathrm{B}(\mathrm{m})$ & EHBA & 60 & & IgG+ & - & - & + & - \\
\hline $\mathrm{C}(\mathrm{f})$ & EHBA & 60 & & IgG+ & - & - & $\ddagger$ & - \\
\hline$D(f)$ & EHBA & 50 & & IgG+ & - & - & + & - \\
\hline $\mathrm{E}(\mathrm{m})$ & EHBA & 105 & & IgG+ & - & - & + & - \\
\hline $\mathrm{F}(\mathrm{f})$ & NS & 55 & & IgG+ & - & - & + & - \\
\hline$G(f)$ & NS & 40 & & & - & - & + & - \\
\hline
\end{tabular}

* At the time of the infant's investigation.

t All infants were IgG+.

$\ddagger$ CMV-DNA by PCR not performed, but CMV was detected on virus isolation.

DNA pellet was dissolved in $50 \mu \mathrm{l}$ distilled water and the DNA used directly for PCR amplification.

Extraction method II

The main difference between extraction methods I and II was that the filter papers were digested with $500 \mu \mathrm{l}$ buffer ( $50 \mathrm{mM}$ TRIS$\mathrm{HCl}$, pH7.5, 0.5\% SDS, $10 \mathrm{mM}$ EDTA and 50 $\mathrm{mM}$ sodium chloride) in method II and $30 \mu \mathrm{l}$ proteinase $\mathrm{K}(10 \mathrm{mg} / \mathrm{ml})$ in $37^{\circ} \mathrm{C}$ overnight. Only one extraction with phenol-chloroform 1:1 was performed and the DNA was dissolved in $100 \mu \mathrm{l}$ distilled water. Method II was also performed on all Guthrie cards with the use of three filter papers (each $3 \mathrm{~mm}$ in diameter) and the DNA was then dissolved in $50 \mu 1$ distilled water.

\section{PCR A}

PCR A was performed on a total volume of 50 $\mu \mathrm{l}$ containing $10 \mathrm{mM}$ TRIS- $\mathrm{HCl}, \mathrm{pH} 8.3,2.1$ $\mathrm{mM} \mathrm{MgCl}, 50 \mathrm{mM} \mathrm{KCl}, 0.5 \mathrm{mM}$ of each deoxynucleotide triphosphate (dNTP), 1 unit Taq DNA polymerase, $50 \mathrm{pmol}$ of each oligonucleotide primer (OP1 and OP2) from the major immediate early region (MIE) (table $3)^{9}{ }^{10}$ and $10 \mu \mathrm{l}$ of the extracted sample. The mixture was overlaid with three drops of paraffin oil to avoid evaporation. Amplification was carried out in a automated thermal cycler with 40 cycles at $94^{\circ} \mathrm{C}$ for 1 minute (DNA denaturation), $60^{\circ} \mathrm{C}$ for 30 seconds (primer annealing), and $65^{\circ} \mathrm{C}$ for 2 minutes (DNA extension).

\section{PCR B}

PCR B consisted of 20 cycles of amplification with the outer primer pair (IEP) $2 \mathrm{~A} / 4 \mathrm{~B}$, thereafter the inner primer pair IEP3A/3B (all located in the major immediate early region of the genome) (table 3) was added to the reaction mixture and another 30 cycles were performed.

Table 3 CMV primers used for PCR A, B, and $C$

\begin{tabular}{|c|c|c|c|}
\hline $\begin{array}{l}\text { Viral region } \\
\text { CMV MIE }\end{array}$ & Localisation & Sequences & Length base pairs \\
\hline OP1 & -22 to -2 & 5'-GCAG AGCT CGTT TAGT GAAC C-3' & \\
\hline OP2 & $66-85$ & 5'-CCGT TCCC GGCC GCGG AGGC-3' & 107 \\
\hline IEP2A & 1479-1498 & 5'-ATGG AGTC CTCT GCCA AGAG-3' & \\
\hline IEP4B & $2182-2201$ & 5'-CAAT ACAC TTCA TCTC CTCG-3' & 723 \\
\hline IEP3A & $1677-1696$ & 5'-GTGA CCAA GGCC ACGA CGTT-3' & \\
\hline IEP3B & $1824-1843$ & 5'-TCTG CCAG GACA TCTT TCTC-3' & 167 \\
\hline
\end{tabular}

$\mathrm{MIE}=$ major immediate early; $\mathrm{OP}=$ oligonucleotide primer; $\mathrm{IEP}=$ immediate early primer.
The PCR was performed on a total volume of $25 \mu \mathrm{l}$ containing $10 \mathrm{mM}$ TRIS- $\mathrm{HCl}, \mathrm{pH} 8.3$, $1.5 \mathrm{mM} \mathrm{MgCl}_{2}, 50 \mathrm{mM} \mathrm{KCl}, 0.2 \mathrm{mM}$ of each dNTP, 0.625 units Taq DNA polymerase, 1 pmol of each primer, IEP2A/4B (table 3) ${ }^{11}$ and $5 \mu \mathrm{l}$ of the extracted sample. The mixture was overlaid with three drops of paraffin oil. The PCR reaction consisted of 20 cycles of DNA denaturation at $94^{\circ} \mathrm{C}$ for 1 minute, primer annealing at $52^{\circ} \mathrm{C}$ for 2 minutes, and primer extension at $72^{\circ} \mathrm{C}$ for 4 minutes. After the first amplification $5.5 \mu \mathrm{l}$ of a reaction mixture composed of $25 \mathrm{pmol}$ of each primer, IEP3A/3B (table 3), ${ }^{11} 0.625$ units Taq polymerase was added to the earlier amplified product; the total volume was $30.5 \mu \mathrm{l}$. This PCR reaction consisted of 30 cycles of DNA denaturation at $94^{\circ} \mathrm{C}$ for 1 minute, primer annealing at $52^{\circ} \mathrm{C}$ for 2 minutes, and primer extension at $72^{\circ} \mathrm{C}$ for 3 minutes.

\section{PCR C}

PCR C was also a nested PCR using the same primers as in PCR B but it consisted of $30+30$ cycles. In this PCR the amplification started with an initial cycle of denaturation at $95^{\circ} \mathrm{C}$ for five minutes, primer annealing at $55^{\circ} \mathrm{C}$ for 30 seconds, and primer extension at $72^{\circ} \mathrm{C}$ for 1 minute followed by 28 similar cycles with the exception of the denaturation time which was only 30 seconds. The last cycle differed only with regard to primer extension time which was 5 minutes. After the first amplification $5 \mu$ of the amplified product was transferred to a new reaction mixture composed as for the first reaction mixture in PCR $B$, except that 25 pmol of each primer IEP3A/3B was used and another 30 cycles were performed.

To minimise PCR cross contamination, separate rooms were used for work before and after PCR. Every separate Guthrie card was run in duplicate and a negative control (distilled water) before and after each separate card was included.

The sample $(15 \mu \mathrm{l})$ was after addition of loading buffer ( $25 \%$ bromphenol blue in $40 \%$ sucrose) separated on 3\% agarose gel. The gel was stained with ethidium bromide and DNA was visualised and photographed under short wave ultraviolet light.

For all three PCR methods a set of HLA DQ primers, GH26/27, ${ }^{12}$ were used as a control of DNA extraction to detect inhibition causing false negative results.

Informed consent was obtained from the parents and the study was approved by the local ethics committee.

\section{Results}

Two different DNA extraction methods from dried blood spots on Guthrie cards and three different CMV DNA PCR systems were compared. Extraction I included four extraction steps. A substantial loss of material was seen with this method and it was also very time consuming. It was also difficult to amplify the control of human HLA DNA in the test material. For extraction II, only one extraction was used and positive results from the amplification of 
the test material as well as the HLA control were obtained.

One of the three PCR systems that were compared was a non-nested (PCR A), and the other two were nested (PCR B and C). All three PCR systems had primers located in the immediate early region. In PCR A, a lot of non-specific bands were seen on agarose gel electrophoresis. The results were easier to interpret with PCR B because fewer nonspecific bands were seen. PCR C gave the most specific reaction patterns on agarose gels because only one specific band was visible in positive specimens. With PCR B and C, CMV DNA could be detected in all dilutions of the CMV harvest from tissue culture.

Based on these observations, extraction method II and PCR C were used for the analyses of patient samples. With the combination of these two methods, CMV was not detected in the two test samples from Guthrie cards prepared with blood from CMV IgG positive adults nor from the two CMV IgG negative adults. As positive controls the Guthrie cards of the eight patients with known congenital CMV infection were tested and they were all CMV DNA positive. The detection limit was $0.1 \mathrm{fg} / \mu \mathrm{l}$, corresponding to $0.4 \mathrm{~mol} \mathrm{CMV} \mathrm{DNA} / \mu \mathrm{l}$.

In group A CMV DNA was detected by PCR on Guthrie cards from two of $32(6 \%)$ infants (cases 6 and 20) (table 1). Case 6 was virologically examined at 2 months of age and case 20 at 1 month of age. Both their mothers were CMV IgM positive when tested at the time of the first investigation. Serum samples from the first trimester were not available for the two mothers. The mother of case 6 reported herself as healthy during her pregnancy, while the mother of case 20 was treated with antibiotics for upper respiratory tract infections twice during the second trimester.

Case 6 was born at full term, her birthweight, length, and head circumference were normal for gestational age. On presentation, she had normal haemoglobin concentrations, white cell count, and platelets. She was diagnosed as having EHBA and underwent portoenterostomy. Case 20 was born at 43 weeks of gestation, and had normal anthropometric measurements at birth. On presentation he was anaemic, but had normal white cells and platelet counts. During the first year of life he developed a chronic intrahepatic cholestasis of the Norwegian type with bilateral lymph oedema of the lower extremities. ${ }^{13}$

The Guthrie cards from all other infants in group A and B (table 2) were CMV DNA negative. There was no difference in results if two or three pieces of the Guthrie cards were used nor if the extracted DNA was dissolved in 50 or $100 \mu \mathrm{l}$ water. Concordant results were in all cases obtained by duplicate analysis. Water controls used as internal controls between each card were all negative. The Guthrie cards stored before and after the cards of the two CMV DNA positive patients were all negative. Guthrie cards from 10 patients were punched out between the two CMV DNA positive cards and all tested negative.

\section{Discussion}

To clarify the role of CMV infection in the aetiology of neonatal cholestasis, it is important to know the time of onset of infection. Mother to infant transmission of CMV can occur either before, during, or after birth. ${ }^{5}$ To our knowledge, no previous study has tried to establish the time of CMV infection in the case of CMV associated neonatal cholestasis, using CMV DNA detection on Guthrie cards by PCR. This method has been used by others to diagnose congenital CMV infection, but not specifically in patients with neonatal cholestasis. ${ }^{7814}$

In our study we found that $6 \%(2 / 32)$ of the patients with neonatal cholestasis and an ongoing CMV infection (group A) had CMV DNA detected in dried blood spots shortly after birth. This would indicate that they were infected prenatally. They were the only infants whose mothers had CMV IgM detected in sera sampled at the time of the infants' investigation. This is compatible with a primary maternal infection during the second half of pregnancy. The exact time of maternal infection remains uncertain in our two cases, as there were no stored first trimester sera available from these mothers. Considering the clinical history of maternal case 20, a primary CMV infection during the second trimester of her pregnancy cannot be ruled out. The two children had no apparent signs of congenital CMV infection at birth, ${ }^{5}$ such as intrauterine growth retardation or haematological abnormalities, except for case 20 being anaemic. This would also suggest an infection during the later part of fetal life.

The sensitivity of the CMV DNA analyses of the Guthrie cards for the detection of known congenital CMV infection was high in our study ( 8 out of 8 detected). This agrees with findings from other studies. ${ }^{814}$ The CMV DNA negative results in the other 30 infants of group $A$ and the seven infants of group B therefore indicate that they were probably not infected prenatally, but rather peri- or postnatally.

In our previous study, ${ }^{4}$ the percentage of cholestatic infants with signs of an ongoing CMV infection was significantly higher than for age matched non-cholestatic controls. This was true not only for the group with intrahepatic neonatal cholestasis, but also for the group with EHBA. The question is, then, what part the virus plays in neonatal cholestasis, given the results of our study. Does the CMV infection have a causative role in the aetiology of neonatal cholestasis? Is it merely aggravating an already established cholestatic process or is it an innocent bystander? A further possibility is that the virus triggers an immunological mechanism, as suggested earlier in the case of EHBA. ${ }^{15}{ }^{16}$ Such mechanisms could explain the fact that in case 6 CMV DNA was detected in the Guthrie card at birth, but not in the liver biopsy specimen at 2 months of age. Another possibility is that a peri-or postnatal infection could start the cholestatic process.

With the availability of antiviral treatment for CMV infection such as ganciclovir, ${ }^{17}$ the question of when CMV is transmitted to these patients and its pathogenic role is not simply of 
academic interest. Ganciclovir is currently being studied for the treatment of confirmed congenital CMV infections. In a recent report it decreased the excretion of CMV in the urine and some patients improved clinically. ${ }^{18} \mathrm{No}$ such controlled study has been completed for CMV associated neonatal cholestasis, although treatment has been reported in a few case studies. ${ }^{19}$ One important question, which might be answered by studies similar to ours, is whether the success rate of such antiviral treatment in cholestatic patients varies with time of onset of CMV infection.

There are also other paediatric patient groups in whom the CMV DNA analysis of blood spots on Guthrie cards could be used to time the transmission of CMV. Thus the likelihood of an association between the infant's disease and CMV infection could be determined and used as a possible basis for antiviral intervention. One example is infants with neurological symptoms, such as seizures or senso-neurological hearing impairment, in whom CMV infection is found after the age of 3 weeks, when it cannot be determined whether it is a congenital infection.

As to the methodology used, much emphasis was laid on the optimisation of the CMV DNA analysis by comparison of several procedures for extraction and cycling conditions. The choice of primers is another important factor influencing the sensitivity. Strain variations at the nucleotide level may occur in different gene regions. Consensus primers covering the entire range of CMV strains have yet to be defined. In our study primers within a well conserved part of the MIE gene region were chosen on the basis of previous experience from controlled comparative studies ${ }^{112021}$ and many years of large scale CMV diagnostic work. CMV DNA detected by PCR based on these primers were also found by virus culture methodology. ${ }^{22}$ Thus it is likely that most CMV strains will be detected. The detection limit of our CMV DNA technique reached a satisfactory level of $0.1 \mathrm{fg} / \mu \mathrm{l}$, corresponding to $0.4 \mathrm{~mol} \mathrm{CMV}$ $\mathrm{DNA} / \mu \mathrm{l}$, yielding positive results in all eight cards from verified cases of congenital CMV infection. Our detection limit is at the same level as that reported in a previous study, ${ }^{14}$ where cards from all 19 congenitally CMV infected infants became positive. We could also verify that the cleaning of the puncher worked out satisfactorily, as well as the precautions taken to avoid contamination from other sources.

In summary, the CMV DNA analysis applied for detection of virus content in blood spots on Guthrie cards was studied regarding procedures for extraction and PCR conditions. In our hands modification of previously published methods was preferred. This is because extraction became less time consuming, with reduced risk for loss of material, and the result in the detection system was more clear cut without non-specific bands. The sensitivity remained high and comparable with the method used and evaluated by others. ${ }^{8}{ }^{14}$ When applied to a group of cholestatic infants with concomitant CMV infection, only two children had demonstrable viraemia at the time of sampling of the Guthrie cards. Serological data on their mothers were compatible with CMV infection later during pregnancy. Finally, in most of the children CMV DNA was not detected in the Guthrie cards, suggesting infection at or after birth.

We are grateful to Claes Guthenberg and Lisbeth Egerfjord at the Swedish PKU Laboratory, Huddinge University Hospital, for their generous help with the stored Guthrie cards. Financial for their generous help with the stored Guthrie cards. Financial support was available from the Foundations of Karolinska Insti-
tute, Jerring and Samariten and from the Swedish Freemason's tute, Jerring
Association.

1 Poley JR. Syndromes of neonatal cholestasis. In: Gracey M, Burke V, eds. Pediatric Gastroenterology and Hepatology, 3rd Burke V, eds. Pediatric Gastroenterology and Hepatology, 3rd
Edn. Boston: Blackwell Scientific Publications, 1993: 566Edn.

2 Morecki R, Glaser JH. Reovirus type 3 and neonatal cholestasis. Semin Liver Dis 1987;2:100-6.

3 Riepenhoff-Talty M, Gouvea V, Evans MJ, et al. Detection of Group C Rotavirus in infants with extrahepatic biliary atresia. $\mathcal{F}$ Infect Dis 1996;174:8-15.

4 Fischler B, Ehrnst A, Forsgren M, Örvell C, Nemeth A. The viral association of neonatal cholestasis in Sweden, a possible link between cytomegalovirus and extrahepatic biliary atresia. F Pediatr Gastroenterol Nutr 1998;27:57-64.

5 Britt WJ, Alford CA. Cytomegalovirus. In: Fields BN, Knipe DM, Howley PM, et al, eds. Fields Virology, 3rd Edn. Philadelphia: Lippincott-Raven Publishers, 1996:2493523.

6 Menghini S. One-second needle biopsy of the liver. Gastroenterology 1958:35:190.

7 Shibata M, Takano H, Hironaka T, Hirai K. Detection of human cytomegalovirus DNA in dried newborn blood filter paper. F Virol Methods 1994;46:279-85.

8 Johansson PJH, Jönsson M, Ahlfors K, Ivarson SA, Svanberg L, Guthenberg C. Retrospective diagnostics of congenital cytomegalovirus infection performed by polymerase chain reaction in blood stored on filter paper. Scand F Infect Dis 1997;29:465-8

9 Olive M, Simsek M, Al Mufti S. Polymerase chain reaction assay for detection of human cytomegalovirus. $\mathcal{F}$ Clin Microbiol 1989;27:1238-42.

10 Olive M, Al Mufti S, Simsek M, Fayez H, Al Nakib W. Direct detection of human cytomegalovirus in urine specimens from renal transplant patients following polymerase mens from renal transplant patients following polymerase
chain reaction amplification. $\mathcal{F}$ Med Virol 1989;29:232-7.

chain reaction amplification. F Med Virol 1989;29:232-7.
11 Porter-Jordan K, Rosenberg E, Keiser J, et al. Nested polymerase chain reaction assay for the detection of cytomegalovirus overcomes false positives caused by concytomegalovirus overcomes false positives caused by con-
tamination with fragmented DNA. F Med Virol tamination with

12 Erlich H, Bugawan T. HLA class II gene polymorphism: DNA typing, evolution and relationship to disease susceptibility. In: Principles and applications for DNA amplification.New York: Stockton press, 1989:193-208.

13 Aagenes O. Hereditary recurrent cholestasis with lymphoedema - two new families. Acta Paediatr Scand 1974;63:465-71.

14 Barbi M, Binda S, Primache V, Luraschi C, Corbetta C. Diagnosis of congenital cytomegalovirus infection by detection of viral DNA in dried blood spots. Clin Diagn Virol 1996;6:27-32.

15 Schreiber RA, Kleinman RE. Genetics, immunology and biliary atresia: An opening or a diversion (Editorial). $\mathcal{F}$ biliary atresia: An opening or a diversio
Pediatr Gastroenterol Nutr 1993;16:111-13.

16 Silveira TR, Salzano FM, Donaldson PT, Mieli-Vergani G, Howard ER, Mowat AP. Association between HLA and extrahepatic biliary atresia. I Pediatr Gastroenterol Nutr 1993;16:114-7.

17 Crumpacker CS. Ganciclovir. N Engl F Med 1996;335:7219.

18 Whitley RJ, Cloud G, Gruber W, et al. Ganciclovir treatment of symptomatic congenital cytomegalovirus infection results of a phase II study. F Infect Dis 1997;175:1080-6.

19 Barbi M, Binda S, Primache V, Novelli C. Cytomegalovirus in peripheral blood leukocytes of infants with congenital or

postnatal infection. Pediatr Infect Dis f 1996;15:898-903. major immediate early gene of human cytomegalovirus major immediate early gene of human cyt
strain AD169. Virus Research 1985;2:107-21

21 Chee MS, Bankier AT, Beck S, et al. Analysis of the proteincoding content of the sequence of human cytomegalovirus
strain AD169. Curr Topics Microbiol Immunol strain AD169.

22 Ehrnst A, Barkholt L, Lewensohn-Fuchs I, et al. CMV PCR monitoring in leucocytes of transplant patients. Clin Diagn Virol 1995;3:139-53. 